\title{
Alternatif Perencanaan Pondasi Tiang untuk Gedung Tinggi di Atas Tanah Lunak pada Proyek Pembangunan Kota Baru Summarecon-Bandung
}

\author{
Ali Kurniawan, Indrasurya B. Mochtar, dan Yudhi Lastiasih. \\ Jurusan Teknik Sipil, Fakultas Teknik Sipil dan Perencanaan, Institut Teknologi Sepuluh Nopember (ITS) \\ Jl. Arief Rahman Hakim, Surabaya 60111 Indonesia \\ e-mail: indrasurya@ce.its.ac.id,yudhi_lastiasih@gmail.com
}

\begin{abstract}
Abstrak-Proyek pembangunan Kota Baru-Summarecon Bandung terletak pada kawasan Gedebage Bandung Timur. Kawasan ini merupakan area bekas sawah sehingga memiliki jenis tanah yang sangat lunak (dominan lempung) dengan NSPT rata-rata sebesar 2. Proyek tersebut masih dalam pelaksanaan konstruksi tahap 1, sehingga belum diketahui desain konstruksi pada gedung yang akan dibangun. Untuk itu perlu adanya permodelan struktur atas yang diklasifikasikan sebagai gedung tinggi $10 \mathrm{Lt}, 15 \mathrm{Lt}$, dan $20 \mathrm{Lt}$, dengan fungsi bangunan sebagai gedung perkantoran.

Dalam tugas akhir ini, dilakukan perencanaan dengan beberapa alternative perencanaan pondasi, yaitu dengan menggunakan metode konvensional dan metode P-y curve. Perencanaan pondasi yang dilakukan adalah sebagai berikut; permodelan struktur gedung menggunakan Program Bantu SAP 2000, perhitungan daya dukung tanah untuk pondasi dengan perumusan Meyerhoff \& Bazaara, perhitungan kebutuhan jumlah tiang dalam kelompok, efisiensi tiang, daya dukung tiang kelompok, safety factor, analisa penurunan tiang menggunakan software allpile, konstanta pegas, perbandingan antara metode konvensional dengan P-y curve, serta perencanaan biaya.

Berdasarkan hasil perencanaan pada tugas akhir ini, didapatkan bahwa, dengan nilai Safety Factor (SF) yang sama yaitu 2, penggunaan metode P-y curve akan lebih efisien karena kebutuhan jumlah tiang pancang lebih sedikit sehingga biaya lebih murah
\end{abstract}

Kata Kunci_Allpile, Daya Dukung, Pondasi Tiang Pancang, Py Curve.

\section{PENDAHULUAN}

$\mathrm{P}$ pulasi penduduk yang semakin bertambah tiap tahun, memerlukan lahan yang lebih besar sebagai sarana penunjang kehidupan. Pada umumnya lahan yang tersedia untuk pembangunan di kota-kota besar relatif kecil, sehingga terkadang bangunan harus didirikan di atas tanah sulit terutama tanah sangat lunak. Masalah utama yang timbul pada tanah sangat lunak antara lain, daya dukung tanah yang sangat rendah, tingkat penurunan tanah yang relatif besar dan tidak merata [1]., serta masalah yang timbul beberapa tahun setelah bangunan didirikan (dinding rumah retak, gap antara lantai bangunan dengan tanah).

Untuk mengatasi permasalahan yang ada, umumnya perencana menggunakan pondasi tiang pancang dalam perencanaan konstruksi pondasi pada suatu gedung. Perencanaan pondasi tiang pancang yang selama ini dipakai adalah berdasarkan daya dukung ujung tiang (end bearing) dan daya dukung selimut tiang (friction bearing) [2]. Perencaaan pondasi tiang pancang ini menggunakan metode konvensional yaitu menggunakan perhitungan dengan mengambil angka kemanan (SF) sebesar 2. Hal ini dimaksudkan untuk mengatasi ketidak-mungkinan penggunaan pondasi dangkal dan penurunan tanah (settlement) yang besar.

Pada kenyataannya terdapat daerah di Indonesia yang memiliki lapisan tanah lunak dengan kedalaman tanah keras yang jauh dari permukaan tanah. Sebagai contohnya adalah tanah yang berada di kota Bandung. Kondisi tanah di Bandung khususnya pada proyek pembangunan kota baru memiliki lapisan tanah lunak dengan $\mathrm{N}_{\text {SPT }}$ rata-rata sebesar 2 , dengan kedalaman tanah keras rata-rata mencapai kedalaman $31 \mathrm{~m}$. Kondisi tersebut menyebabkan penggunaan tiang pancang yang tidak ekonomis, sehingga perlu dilakukan alternatif perhitungan pondasi lain yaitu dengan menggunakan pondasi tiang pancang dengan metode $p$-ycurve

\section{URAIAN PERENCANAAN PONDASI}

\section{A. Perhitungan Struktur Atas}

Perhitungan struktur atas ditujukan untuk mendapatkan besarnya gaya-gaya yang bekerja akibat struktur gedung, guna mengetahui jumlah kebutuhan pondasi.

\section{Pembebanan Struktur}

Pembebanan struktur utama terdiri dari

- Beban mati ,

Berat dari semua bagian dari suatu struktur yang bersifat tetap

- Beban hidup,

Beban yang terjadi akibat penghuniaan atau penggunaan suatu gedung.

- Beban gempa.

Gaya-gaya yang berasal dari gerakan tanahyang dikombinasi dengan sifat dinamis struktur. Beban gempa dihitung menggunakan cara analitis seperti pada SNI 1726-2012

\section{Perencanaan Dimensi Struktur}

Perencanaan dimensi struktur ditujukan untuk mendapatkan beban-beban kerja yang digunakan dalam perhitungan gayagaya dalam pada aplikasi SAP2000.Struktur yang direncanakan terdiri dari, balok induk, balok anak, kolom, pelat lantai. 


\section{SAP2000}

Aplikasi SAP2000 digunakan untuk menganalisa gaya-gaya yang bekerja, dengan memasukan terlebih dahulu pembebanan dan dimensi struktur yang telah direncanakan.

\section{B. Perhitungan Daya Dukung Tanah}

Perhitungan daya dukung tanah terhadap tiang meliputi perhitungan daya dukung ujung tiang (endbearing) maupun daya dukung selimut tiang (skinfriction) positif maupun negatif. Sebelum melakukan perhitungan daya dukung, terlebih dahulu nilai $\mathrm{N}_{\mathrm{SPT}}$ dikoreksi terhadap muka air dan terhadap overburden pressure tanah [3].

\section{Koreksi terhadap Muka Air}

Koreksi dilakukan khusu untuk tanah pasir halus, pasir berlanau, dan pasir berlempung yang berada dibawah muka air tanah dan hanya bila $\mathrm{N}>15$ [3].

\section{Koreksi terhadap Overburden Pressure}

Hasil koreksi dari muka air dikoreksi kembali terhadap pengaruh tekanan vertikal efektif pada lapisan tanah dimana harga $\mathrm{N}_{\mathrm{SPT}}$ tersebut didapatkan [3].

\section{Perhitungan Kebutuhan Tiang Kelompok}

Perhitungan kebutuhan tiang kelompok bertujuan untuk mendapatkan jumlah tiang pada satu perletakan kolom. Hasil perhitungan tersebut dikontrol terhadap gaya yang bekerja akibat struktur gedung dan dikontrol terhadap safety factor- nya [2].

\section{Perhitungan Jumlah Tiang}

Perhitungan jumlah tiang didapat dengan membagi gaya yang bekerja akibat struktur dengan daya dukung tanah [2]. Dalam tugas ini, daya dukung tanah yang diambil adalah yang mendekati dan kurang dari setengah kapasitas tiang. Penggunaan setengah kapasitas tiang adalah untuk mencegah terjadi nya kehancuran tiang saat pemancangan.

\section{Konfigurasi Tiang}

Dari perhitungan jumlah tiang yang dibutuhkan, ditentukan konfigurasi tiang yang dapat digunakan. Konfigurasi tiang tersebut dapat dilihat pada Gambar.1. Jarak antar tiang (d) digunakan jarak 2.5-3D, dimana $\mathrm{D}$ adalah diameter tiang. Jumlah tiang arah $\mathrm{X}(\mathrm{n} 1)$ dan arah $\mathrm{Y}(\mathrm{n} 2)$ disesuaikan dengan jumlah kebutuhan tiang. Konfigurasi tiang dapat dilihat pada gambar 1.

\section{Efisiensi}

Efisiensi tiang dihitung berdasar kan rumusan :

$$
\mu=1-\left[\frac{\left(n_{1}-1\right) n_{2}+\left(n_{2}-1\right) n_{1}}{90 n_{1} n_{2}}\right] \theta
$$

Dimana :

$$
\begin{array}{ll}
\mu & =\text { Efisiensi Tiang } \\
\mathrm{n}_{1} & =\text { Jumlah tiang arah sumbu } \mathrm{x} \\
\mathrm{n}_{2} & =\text { Jumlah tiang arah sumbu } \mathrm{y} \\
\theta & =\tan ^{-1}(\mathrm{D} / \mathrm{d}) \\
\mathrm{D} & =\text { Diameter Tiang Pancang }
\end{array}
$$

D = Jarak antar Tiang

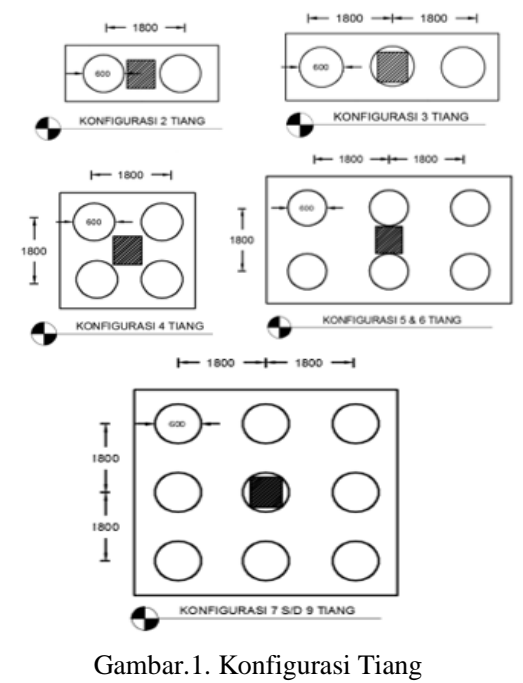

\section{Daya Dukung dalam Kelompok}

Daya dukung kelompok adalah hasil jumlah seluruh daya dukung satu tiang dikalikan dengan efisiensi satu tiang [2]. Dapat dihitung dengan rumusan :

$$
Q_{g(u)}=\mu x \sum Q_{u}
$$

Dimana :

$$
\begin{aligned}
\mathrm{Q}_{\mathrm{g}(\mathrm{u})} & =\text { Daya Dukung Tiang Dalam Kelompok } \\
\mu & =\text { Efisiensi Tiang } \\
\Sigma \mathrm{Q}_{\mathrm{u}} & =\text { Daya Dukung Satu Tiang x Jumlah Tiang }
\end{aligned}
$$

\section{Safety Factor}

Perhitungan safety factor ditujukan untuk mengetahui aman atau tidaknya suatu perencanaan. Pada perencanaan pondasi tiang ini, besarnya daya dukung kelompok dibagi dengan beban kerja pada struktur tidak boleh lebih kecil dari 2.

\section{Perhitungan Beban Maksimum Tiang}

Beban maksimum yang bekerja pada satu tiang dihitung berdasarkan gaya aksial dan momen yang bekerja. Perhitungan ini dilakukan untuk nilai SF lebih besar maupun lebih kecil dari 2. Tujuannya adalah untuk mengetahui penambahan (untuk SF $<2$ ) atau pengurangan jumlah tiang (untuk $\mathrm{SF} \geq 2$ ) sehingga mendapatkan konfigurasi tiang yang efisien (kebutuhan tidak kurang atau terlalu berlebihan).

\section{Perhitungan Penurunan Tiang (Software Allpile)}

Hasil analisa SAP2000 untuk perletakan jepit dan konfigurasi serta jumlah tiang yang didapatkan dari perhitungan sebelumnya digunakan sebagai input pada aplikasi ini. Penggunaan aplikasi ini bertujuan untuk mendapatkan besarnya penurunan tiang yang terjadi dan besar nilai konstanta pegas.

\section{Input}

Adapula hal-hal yang perlu di-input terlebih dahulu pada aplikasi ini antara lain :

- Pile Type

- Pile Profile

- Pile Properties 
- Load and Group

- Soil Propeties

- Advance Page

\section{Output}

Hasil output aplikasi ini adalah grafik antara gaya yang bekerja $(\mathrm{P})$ dengan penurunan yang terjadi $(\mathrm{y})$ dapat dilihat pada gambar 2 .

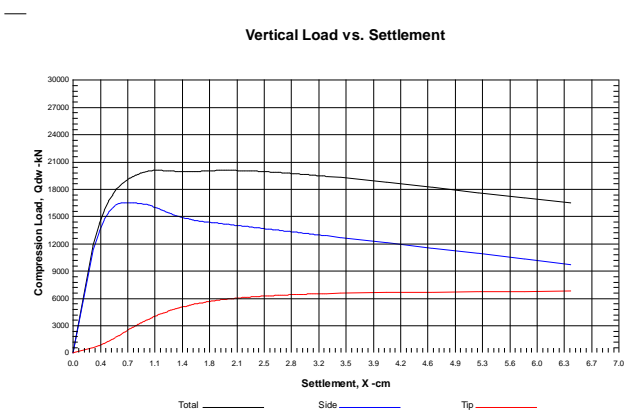

Gambar 2. Kurva Load (P) vs Settlement (y)

\section{E. Perhitungan Konstanta Pegas}

Perhitungan konstanta pegas didapat setelah analisa allpile dilakukan. Nilai konstanta pegas adalah besarnya gaya yang bekerja dibagi dengan penurunan yang terjadi.

$$
k=\frac{P}{y}
$$

Dimana :

$\mathrm{k}=$ Konstanta pegas

$\mathrm{P}$ = Gaya aksial yang bekerja

$\mathrm{y}=$ Penurunan tiang yang terjadi.

\section{F. Perhitungan Kebutuhan Tiang Kelompok Metode P-y} Curve

Perhitungan kebutuhan tiang kelompok untuk metode $P-y$ Curve sama dengan perhitungan kebutuhan tiang sebelumnya.

\section{HASIL DAN ANALISA}

\section{A. Gaya yang Bekerja}

Gaya yang bekerja yang dianalisa adalah gaya aksial dan momen pada kolom. Dari perhitungan yang ada dan analisa menggunakan SAP2000 didapatkan bahwa gaya-gaya yang bekerja pada perencanaan struktur dengan desain perletakan jepit (conventional method) memiliki hasil yang lebih besar daripada perencanaan struktur dengan desain perletakan spring $(P-y$ curve method). Besar perbandingan gaya-gaya yang bekerja pada kedua metode tersebut (satu titik untuk setiap gedung) dapat dilihat pada tabel 1 .

\section{B. Jumlah Tiang Pakai}

Jumlah tiang pakai pada metode P-y curve lebih sedikit daripada metode konvensional. Hal tersebut terjadi akibat perbedaan gaya yang cukup besar antara kedua metode sehingga kebutuhan tiang juga berbeda. Hasil perbandingan jumlah tiang pakai untuk kedua metode dapat dilihat pada tabel 2.

\section{Penulangan}

Tabel 1. Tabel Perbandingan Gaya yang Bekerja (Kolom 6A) untuk Setiap Gedung

\begin{tabular}{ccccc}
\hline \multirow{2}{*}{ Metode } & $\begin{array}{c}\text { Jenis } \\
\text { Gedung }\end{array}$ & $\begin{array}{c}\text { Aksial } \\
\text { (ton) }\end{array}$ & $\begin{array}{c}\text { Momen } \\
\mathbf{X} \\
(\mathbf{~ t m})\end{array}$ & $\begin{array}{c}\text { Momen } \\
\mathbf{Y} \\
\text { ( tm })\end{array}$ \\
\hline \multirow{3}{*}{ Konvensional } & $10 \mathrm{Lt}$ & 287.95 & 205.21 & 191.66 \\
\cline { 2 - 5 } & $15 \mathrm{Lt}$ & 492.56 & 379.74 & 351.79 \\
\cline { 2 - 5 } P-y Curve & $20 \mathrm{Lt}$ & 685.22 & 434.59 & 403.10 \\
\cline { 2 - 5 } & $10 \mathrm{Lt}$ & 288.83 & 0.05 & 0.00 \\
\cline { 2 - 5 } & $15 \mathrm{Lt}$ & 685.22 & 0.12 & 0.15 \\
\hline & $20 \mathrm{Lt}$ & 493.03 & 0.05 & 0.05 \\
\hline
\end{tabular}

Tabel 2. Perbandingan Jumlah Tiang Pakai untuk Setiap Gedung

\begin{tabular}{ccc}
\hline Metode & $\begin{array}{c}\text { Jenis } \\
\text { Gedung }\end{array}$ & $\begin{array}{c}\text { Jumlah } \\
\text { Tiang }\end{array}$ \\
\hline \multirow{3}{*}{ Konvensional } & $10 \mathrm{Lt}$ & 306 \\
\cline { 2 - 3 } & $15 \mathrm{Lt}$ & 324 \\
\cline { 2 - 3 } & $20 \mathrm{Lt}$ & 423 \\
\hline \multirow{3}{*}{ P-y Curve } & $10 \mathrm{Lt}$ & 104 \\
\cline { 2 - 3 } & $15 \mathrm{Lt}$ & 140 \\
\cline { 2 - 3 } & $20 \mathrm{Lt}$ & 208 \\
\hline
\end{tabular}

Perhitungan jumlah tulangan digunakan untuk menganalisa kelayakan dimensi balok dengan kebutuhan jumlah tulangannya. Pada perhitungan penulangan dimensi balok tidak perlu dilakukan perencanaan ulang, karena tulangan yang dibutuhkan tidak menyebabkan overreinforced $\left(\rho_{\text {perlu }} \leq\right.$ $\rho_{\text {minimum }}$ ), sehingga tulangan balok akan leleh lebih dahulu sebelum balok hancur [4]. Dengan dimensi balok yang sama dan nilai $\rho_{\text {minimun }}$ yang sama untuk kedua metode, menghasilkan jumlah kebutuhan tulangan yang sama. Hasil perbandingan dimensi balok dan jumlah tulangan pada kedua metode tersebut (satu titik untuk setiap gedung) dapat dilihat pada tabel 3.

\section{Kontrol Lebar Retak}

Tabel 3. Perbandingan Dimensi dan Jumlah Tulangan pada Balok (Balok 6AB) untuk Setiap Gedung

\begin{tabular}{cccc}
\hline Metode & $\begin{array}{c}\text { Jenis } \\
\text { Gedung }\end{array}$ & $\begin{array}{c}\text { Dimensi } \\
(\mathbf{c m})\end{array}$ & $\begin{array}{c}\text { Jumlah } \\
\text { Tulangan }\end{array}$ \\
\hline \multirow{3}{*}{ Konvensional } & $10 \mathrm{Lt}$ & $400 \times 600$ & 12 \\
\cline { 2 - 4 } & $15 \mathrm{Lt}$ & $400 \times 600$ & 12 \\
\cline { 2 - 4 } P-y Curve & $20 \mathrm{Lt}$ & $600 \times 900$ & 22 \\
\cline { 2 - 4 } & $10 \mathrm{Lt}$ & $400 \times 600$ & 12 \\
\cline { 2 - 4 } & $15 \mathrm{Lt}$ & $400 \times 600$ & 12 \\
\hline
\end{tabular}

Kontrol lebar retak dilakukan setelah perhitungan tulangan untuk mengetahui kelayakan dimensi kolom dan jumlah tulangan agar tidak terjadi keretakan yang dapat menyebabkan keruntuhan pada balok. Batas lebar retak maksimum untuk balok interior adalah $0.3 \mathrm{~mm}$ dan $0.4 \mathrm{~mm}$ untuk balok eksterior [4]. Hasil perbandingan lebar retak pada kedua metode tersebut (satu titik untuk setiap gedung) dapat dilihat pada tabel 4

\section{E. Biaya}

Biaya dihitung berdasarkan jumlah tiang pancang yang dipakai untuk setiap gedung pada masing-masing alternatif. Biaya yang dikeluarkan pada metode $P-y$ curve lebih murah dibandingkan dengan metode konvensional. Perbandingan biaya untuk masing-masing metode dapat dilihat pada tabel 5 . 
Tabel 4. Perbandingan Lebar Retak pada Balok (Balok 6AB) untuk Setiap Gedung

\begin{tabular}{ccc}
\hline \multirow{2}{*}{ Metode } & $\begin{array}{c}\text { Jenis } \\
\text { Gedung }\end{array}$ & $\begin{array}{c}\text { Lebar Retak } \\
(\mathbf{m m})\end{array}$ \\
\hline \multirow{3}{*}{ Konvensional } & $10 \mathrm{Lt}$ & 0.17 \\
\cline { 2 - 3 } & $15 \mathrm{Lt}$ & 0.17 \\
\cline { 2 - 3 } & $20 \mathrm{Lt}$ & 0.20 \\
\hline \multirow{2}{*}{ P-y Curve } & $10 \mathrm{Lt}$ & 0.17 \\
\cline { 2 - 3 } & $15 \mathrm{Lt}$ & 0.17 \\
\cline { 2 - 3 } & $20 \mathrm{Lt}$ & 0.20 \\
\hline
\end{tabular}

Tabel 5. Perbandingan Biaya untuk Setiap Gedung

\begin{tabular}{cccc}
\hline Metode & $\begin{array}{c}\text { Jenis } \\
\text { Gedung }\end{array}$ & \multicolumn{1}{c}{ Biaya (Rp) } \\
\hline \multirow{3}{*}{ Konvensional } & $10 \mathrm{Lt}$ & $\mathrm{Rp}$ & $4,828,924,800.00$ \\
\cline { 2 - 4 } & $15 \mathrm{Lt}$ & $\mathrm{Rp}$ & $5,112,979,200.00$ \\
\cline { 2 - 4 } & $20 \mathrm{Lt}$ & $\mathrm{Rp}$ & $6,675,278,400.00$ \\
\hline \multirow{3}{*}{ P-y Curve } & $10 \mathrm{Lt}$ & $\mathrm{Rp}$ & $\mathbf{1 , 6 4 1 , 2 0 3 , 2 0 0 . 0 0}$ \\
\cline { 2 - 4 } & $15 \mathrm{Lt}$ & $\mathrm{Rp}$ & $\mathbf{2}, 209,312,000.00$ \\
\cline { 2 - 4 } & $20 \mathrm{Lt}$ & $\mathrm{Rp}$ & $3,282,406,400.00$ \\
\hline
\end{tabular}

\section{KESIMPULAN/RINGKASAN}

Untuk Safety Factor $(\mathrm{SF})=2$, perhitungan menggunakan metode P-y curve menghasilkan jumlah kebutuhan tiang pancang yang lebih sedikit dibandingkan dengan metode konvensional. Sehingga biaya material yang dikeluarkan untuk metode P-y curve lebih murah dibandingkan dengan metode konvensional.

\section{UCAPAN TERIMA KASIH}

Ali Kurniawan Ngunaidi mengucapkan terima kasih kepada Prof.Ir.Indrasurya BM, MSc. PhD. dan Dr. Yudhi Lastiasih, ST.MT. atas bimbingannya dalam proses pengerjaan tugas akhir ini sehingga dapat terselesaikan. Terima kasih kepada teman-teman sipil angkatan 2012 yang telah mendukung dalam penyelesaian tugas akhir ini.

\section{DAFTAR PUSTAKA}

[1] Bowles, Joseph. E. 1988. Analisis dan Desain Pondasi jilid 1\&2. Jakarta : Penerbit Erlangga

[2] Das, Braja M.1990. Principles Of Foundation Engineering $2^{\text {nd }}$ Edition. Jakarta : Erlangga.

[3] Jurusan Teknik Sipil FTSP-ITS. 2002. Modul H : Perencanaan Tiang Pancang. Surabaya : Jurusan Teknik Sipil FTSP - ITS

[4] Badan, Standarisasi Nasional. (2002). Persyaratan Beton Struktural Untuk Bangunan Gedung (SNI 2847-2002). Jakarta:BSNI 